\title{
Partial villous atrophy in nutritional megaloblastic anaemia corrected by folic acid therapy
}

\author{
D. W. DAWSON \\ From Crumpsall Hospital, Manchester
}

SYNOPSIS A patient with megaloblastic anaemia due to nutritional folate deficiency is described. Partial villous atrophy and malabsorption of xylose showed progressive improvement to normal with folic acid therapy.

Evidence of temporary malabsorption has been reported in a few patients with megaloblastic anaemia due to nutritional folate deficiency (Bickers and Sekinger, 1964; Winawer, Sullivan, Herbert, and Zamcheck, 1965; Siang, England, and O'Brien, 1966; Forshaw, 1969). The small intestinal mucosa in this condition is usually histologically normal but partial villous atrophy was observed in two Indian patients in Singapore by Siang et al (1966) and has been suspected in patients in Britain (Forshaw, 1968). However, no instance of the correction of such mucosal damage by folic acid has been recorded. A patient with nutritional folate deficiency in whom villous atrophy of the jejunum and evidence of malabsorption were corrected by folic acid therapy is therefore reported.

\section{Case History}

H.M., a woman aged 45 years, was admitted to the Manchester Victoria Memorial Jewish Hospital under Mr R. Hartley for cholecystectomy. She complained of nausea, vomiting, and loss of weight. She said that she had been vomiting intermittently since her only pregnancy 18 years before. At first she vomited only food but in recent years fluids, even water, were also returned and she had some anorexia. Barium meal examinations had been carried out three times in the last 10 years, with negative results, and a diagnosis of nervous dyspepsia made. Two and a half years ago she went to Dar es Salaam. While there her symptoms were no worse. On return to this country, four months before admission, nausea and anorexia worsened and she 'didn't keep a meal down'. Loss of weight became marked while abroad, and she estimated that she had lost 6 stone $(12 \cdot 7 \mathrm{~kg})$ in the last two years. She had had occasional griping Received for publication 27 July 1970. abdominal pains recently, but had never had diarrhoea. Amenorrhoea had developed two years ago but curettage and hormone therapy (preparation unknown) restored regular menses until four months before admission, when amenorrhoea recurred. She took no more hormone tablets. She had taken Nembutal $200 \mathrm{mg}$ nightly for some years and continued to take these capsules throughout the whole period of follow up.

On examination no abnormality was detected other than smoothness of the tongue and pallor. Her weight was $45 \mathrm{~kg}$. A cholecystogram showed a non-functioning gallbladder. The discovery of anaemia led to postponement of the operation and the patient's referral to the Haematology Department.

\section{INVESTIGATIONS}

The haemoglobin was $6.6 \mathrm{~g} / 100 \mathrm{ml}$, mean corpuscular haemoglobin concentration $31 \%$, mean cell volume $123 \mathrm{c} \mu$. Bone marrow showed gross megaloblastic changes and increased iron stores. The serum iron concentration was $70 \mu \mathrm{g} / 100 \mathrm{ml}$ and the prothrombin activity $80 \%$. The Schilling test was normal and a simultaneous folic acid absorption test without prior saturation gave only a small serum increment, indicative of either malabsorption or severe tissue folate deficiency. The results of other tests are shown in the Table.

\section{PROGRESS}

The patient's treatment started with daily intramuscular injections of $1 \mathrm{mg}$ cyanocobalamin, the first being the 'flushing' dose of the Schilling test. An improvement in general well being was soon felt. More striking was the improvement in appetite, and by the third day she was eating all the normal ward diet without vomiting. Six injections of vitamin $\mathbf{B}_{12}$ 


\begin{tabular}{|c|c|c|c|c|c|c|c|c|c|c|c|}
\hline Date & $\begin{array}{l}\text { Weight } \\
(k g)\end{array}$ & $\begin{array}{l}\text { Haemoglobin } \\
(\mathrm{g} / 100 \mathrm{ml})\end{array}$ & $\begin{array}{l}\text { Serum } \\
\text { Folate } \\
(\mathrm{ng} / \mathrm{ml})\end{array}$ & $\begin{array}{l}\text { Serum } \\
\text { Vitamin } \\
B_{12}(p g / m l)\end{array}$ & $\begin{array}{l}\text { Postabsorption } \\
\text { Serum Folate } \\
\text { (ng/ml) } \\
\text { (Str. faecalis) }\end{array}$ & $\begin{array}{l}\text { Schilling Test } \\
\text { Urine } \\
\text { Excretion (\%) }\end{array}$ & $\begin{array}{l}\text { Seru: } \\
\mathrm{CaP} \\
(\mathrm{mg})\end{array}$ & $\begin{array}{l}P \\
P \\
(100 \mathrm{ml})\end{array}$ & $\begin{array}{l}\text { Alkaline } \\
\text { Phosphatase } \\
(K A \text { units } / 100 \mathrm{ml})\end{array}$ & $\begin{array}{l}\text { Five-hr } \\
\text { Urine } \\
\text { Xylose }^{2}\end{array}$ & $\begin{array}{l}\text { Faecal Fat } \\
\text { (g/day) }\end{array}$ \\
\hline $\begin{array}{l}17.10 .68 \\
29.10 .68\end{array}$ & 45 & $\begin{array}{l}6 \cdot 3 \\
8 \cdot 8\end{array}$ & $0 \cdot 2$ & 85 & $\begin{array}{l}20^{1} \\
62\end{array}$ & 20 & $8 \cdot 0$ & $4 \cdot 7$ & 12 & 0.4 & $2 \cdot 6$ \\
\hline 23.12 .68 & 52 & $13 \cdot 6$ & $30 \cdot 0$ & 105 & 99 & & $9 \cdot 2$ & & & $1 \cdot 1$ & \\
\hline 4. 8.69 & 57 & $11 \cdot 7$ & $25 \cdot 0$ & 65 & 90 & 24 & $8 \cdot 8$ & $3 \cdot 6$ & 8 & 1.4 & $4 \cdot 0$ \\
\hline
\end{tabular}

Table Patient's data on presentation and following treatment

Normal serum folate $3 \cdot 0-8 \cdot 0 \mathrm{ng} / \mathrm{ml}$

'Patient unsaturated.

$25 \mathrm{~g}$ dose (Santini, Sheehy, and Martinez de Jesus, 1961), normal excretion $>1 \cdot 2 \mathrm{~g}$.

had been given before the microbiological assays were available. Three daily intramuscular injections of $15 \mathrm{mg}$ folic acid were then given and the folic acid absorption test was repeated, this time with a normal result. The initial doses of vitamin $B_{12}$ and folic acid $(1.8 \mathrm{mg})$ produced a reticulocyte response of $26 \%$ on the ninth day. The first jejunal biopsy was taken on the 12th day and was reported as follows: 'The villi are extremely stunted or club shaped; in areas the surface is flat. The brush border is indistinct and the nuclei of the surface epithelium are generally more oval than normal. Goblet cells and Paneth cells are normal. Polymorphs are numerous in the stroma and plasma cells are present in somewhat increased numbers' (Fig. 1). A dissecting microscope was not available but the specimen was re-embedded and cut at several angles of the chuck and the villous pattern was abnormal in every section.

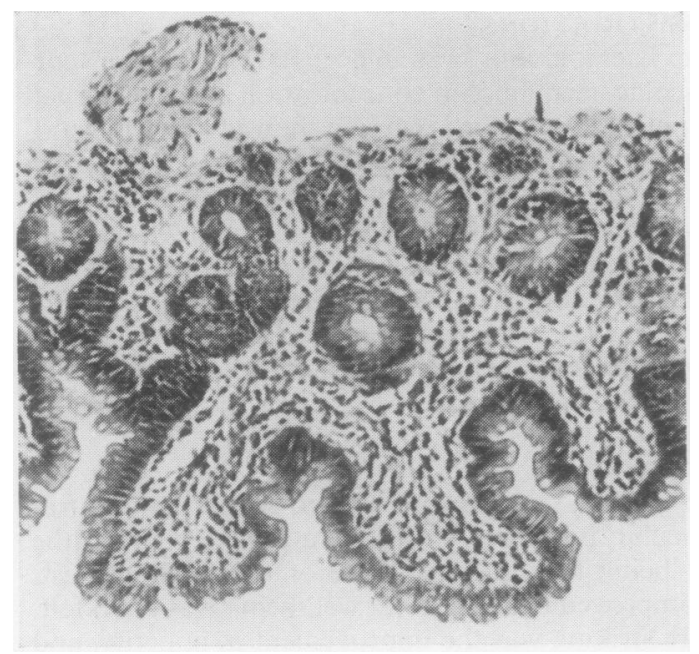

Fig. 1. First jejunal biopsy showing marked flattening of the mucosal surface. $H \& E \times 65$.
Treatment was continued with oral folic acidis $15 \mathrm{mg}$ daily, to which oral iron was added two weeks later. She was discharged from hospital on the $21 \mathrm{st}-$ day with a haemoglobin of $10 \cdot 4 \mathrm{~g} / 100 \mathrm{ml}$ to live in the south of England. She returned after two months? for review, when both the jejunal mucosa and xyloseabsorption had improved. She was feeling well. The second biopsy report read: 'A few stunted villi arê still present but most appear normal, as does the ${ }^{-}$ surface epithelium in which the nuclei are narrow $\overrightarrow{0}$ and peg-like. There is no stromal inflammatory infiltrate. Adenosine triphosphatase activity is normal. Fat droplets are present within the surface epithelium and in the underlying stroma, but noe particularly in the region of the basement membrane (Fig. 2). Iron therapy was stopped and folic acio continued for another seven months when she was seen again. She was eating a good diet and has, gained further weight. She did, however, complain of some nausea and upper abdominal distension fo the previous 10 days. Xylose absorption was normal The jejunal biopsy was normal: 'dissecting micro용 scope appearance of finger-like villi with some ridges:Section shows a normal villous pattern' (Fig. 3) 3 . Each biopsy had been taken with a Watson capsule from the jejunum between 10 and $15 \mathrm{~cm}$ from the ligament of Treitz.

\section{Discussion}

The patient described here had severe folate de ficiency. On admission she had in addition subs normal serum vitamin $B_{12}$ and calcium levels witk malabsorption of xylose, but not of vitamin $B_{12}$ folic acid, or fat. Jejunal biopsy showed partiab villous atrophy. With vitamin $\mathbf{B}_{12}$ and folic aciō therapy xylose absorption and the jejunal mucosa became normal. Ten months after the start of treat ment the only detectable abnormality was a low? serum vitamin $\mathbf{B}_{12}$ level. Because this was subnorma nine weeks after six injections of $1 \mathrm{mg}$ cyanoco $\mathbb{Q}$ balamin and continuous oral folic acid and because 


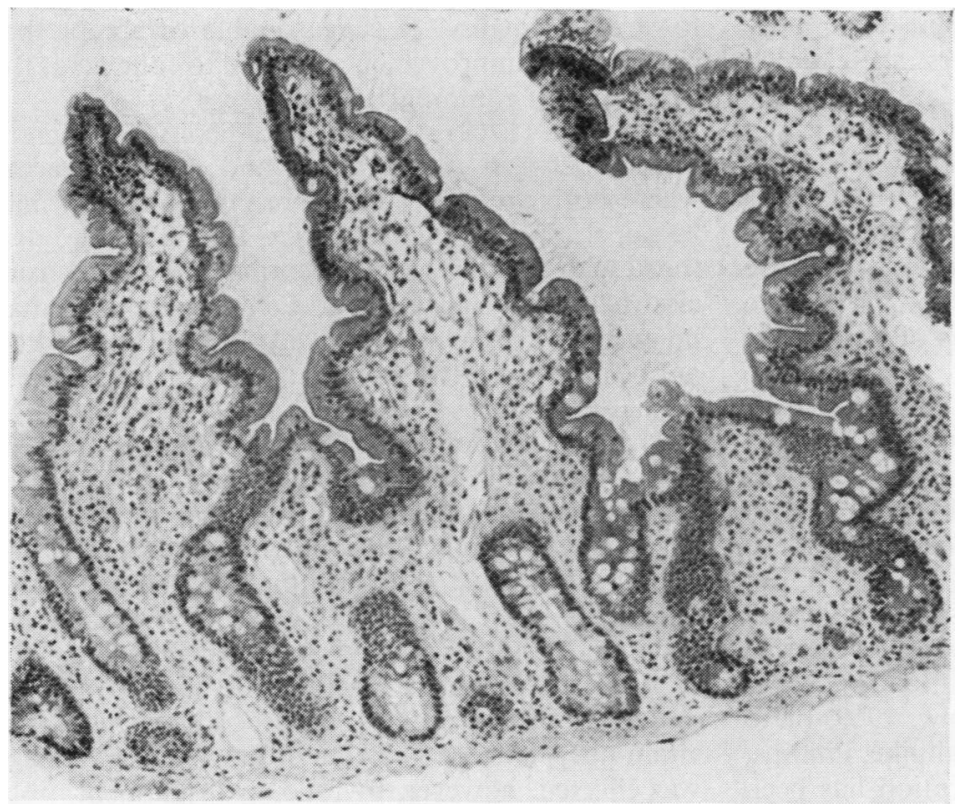

Fig. 2. Biopsy after two months' treatment. Considerable improvement in villous pattern. Frozen section, $H \& E \times 65$.

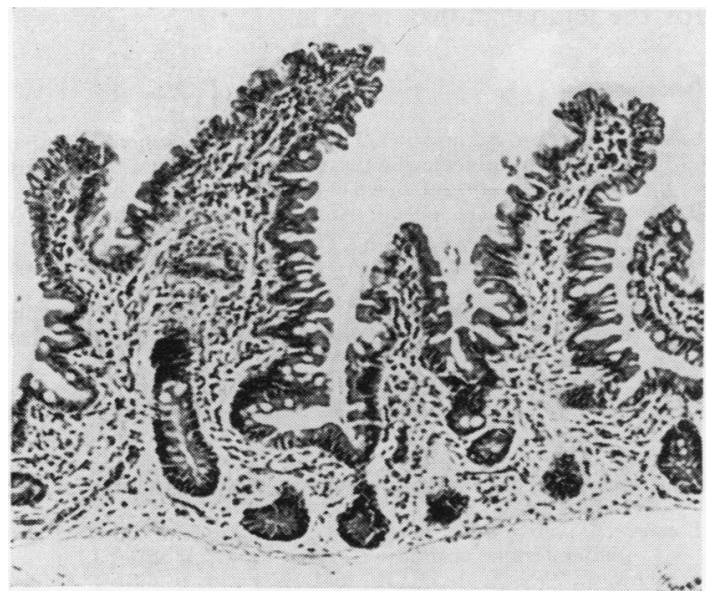

Fig. 3. Normal jejunal biopsy after 10 months' treatment. $H \& E \times 65$.

vitamin $B_{12}$ absorption was normal it is unlikely that it was due either to tissue deficiency or secondary to folate deficiency; nor is it likely that the gut improvement was due to vitamin $B_{12}$ therapy.

The differential diagnosis includes tropical sprue, idiopathic steatorrhoea, and nutritional folate deficiency with secondary jejunal villous atrophy. The first condition is unlikely because sprue does not occur in East Africa, although doubtful cases have been described (Harries, 1964) and because the history preceded her stay overseas. A diagnosis of idiopathic steatorrhoea, in which evidence of malabsorption may be insignificant, is less easy to refute. It has been thought that a normal biopsy taken from the area of the ligament of Treitz virtually excludes the diagnosis of adult coeliac disease (MacDonald, Dobbins, and Rubin, 1965) and it is generally accepted that when the mucosal damage in this condition varies it is worst in the proximal small bowel (Cooke, 1968). For this reason subsequent biopsies were taken as close to the same site as possible. A multiple biopsy technique (Roy-Choudhury, Cooke, Banwell, and Smits, 1967) showed that there may be considerable variation in the severity of the lesion in parts of the proximal jejunum within a few centimetres of each other, and of particular importance was the finding of one normal area in each of six patients. But, as Roy-Choudhury and his colleagues (1967) stressed, a normal biopsy in untreated adult coeliac disease was rare, being found in only three of 88 specimens from 23 new patients. In view of these figures, the failure to obtain a typical biopsy picture of subtotal villous atrophy and the sequence of improving biopsy findings without the use of a gluten-free diet were considered to be very strong evidence against a diagnosis of adult coeliac disease.

It was difficult to obtain a satisfactory dietary 
history because, although the patient apparently took a reasonable diet for some years, she claimed that she vomited all foods. This could not have been strictly true but her previous history clearly indicated that she had had some gastric disturbance for many years. Psychiatric factors are frequently responsible for nutritional folate deficiency in this country. Her obvious loss of weight supported the story of more recent anorexia and, with the correction of the one abnormal absorption test, a diagnosis of nutritional folate deficiency was made.

The taking of contraceptive drugs has been associated with true jejunal atrophy (Watson and Murray, 1966) but in this patient the hormone therapy was not thought to be of aetiological significance because her condition continued to deteriorate for four months after its withdrawal.

There are a number of reports of abnormal absorption tests in folate deficiency either due to malnutrition (Bickers and Sekinger, 1964; Winawer et al, 1965; Siang et al, 1966; Forshaw, 1969) or to anticonvulsant therapy (Reynolds, Hallpike, Phillips, and Matthews, 1965). The malabsorption has been of either vitamin $\mathbf{B}_{12}$ or xylose or both; in one patient there was also steatorrhoea (Siang et al, 1966). Tests repeated after folic acid therapy have been normal (Bickers and Sekinger, 1964; Reynolds et al, 1965; Forshaw, 1969). The small bowel is usually normal in nutritional folate deficiency (Gough, Read, McCarthy, and Waters, 1963) though in some patients minor cellular and histological changes have been observed (Forshaw, Moorhouse, and Harwood, 1964; Winawer et al, 1965; Siang et al, 1966; Wheby, Swanson, and Bayless, 1968) and in two Indians in Singapore (Siang et al, 1966) there was partial villous atrophy. Unfortunately a biopsy after treatment was not taken from any of the 11 patients with malnutrition recorded as having an abnormal jejunum.

The mucosal damage of sprue usually regresses with folic acid therapy (O'Brien and England, 1966; O'Brien, 1968). It has been suggested that this improvement indicates the aggravating effect of folate deficiency on the underlying lesion (Wheby et al, 1968). Bowel improvement might therefore be expected in some other patients with folate deficiency and an abnormal mucosa, though this does not occur in coeliac disease (Butterworth, 1968). Cooke, Fone, Cox, Meynell, and Gaddie (1963) reported a series of 20 cases of folic acid deficiency which are of interest in this respect. The cause of the deficiency was unknown, though two suffered from malnutrition and subsequent follow up has shown only two to have coeliac disease (Cooke, 1970). Sixteen biopsied initially had minor jejunal changes and the six biopsied again after treatment showed change towards normality. It is reasonable to accept that such regular improvement was due to folic acid, the only therapy common to all patients.

Chanarin (1969) stresses the difficulty in differen tiation between malnutrition and sprue in areas where both are rife, and where one condition may be superimposed on the other. But this case, and those with temporary malabsorption reported fron elsewhere, demonstrate that a similar problem mas be encountered in non-tropical areas, which would not be resolved by the obtaining of a single abnormal jejunal biopsy.

There are several possibilities why this patien? had a more abnormal jejunal mucosa than others with nutritional deficiency, including such factoris as the severity and duration of the deficiency, this taking of the first biopsy soon after admission tis hospital, and the presence of additional but unknown aetiological agents. The last is supported by tho unusual finding of a marked polymorph mucosat infiltrate and the persistently subnormal serumb vitamin $B_{12}$ level. Correction of the mucosal damago was effected, however, by folic acid treatment.

I wish to thank Drs R. Pell-Ilderton and H. Wacks for the jejunal biopsy reports.

\section{References}

Bickers, J. N., and Sekinger, D. J. (1964). Radioisotopes in the dia nosis of hematologic manifestations of gastrointestinal disease. Amer. J. dig. Dis., 9, 634-640.

Butterworth, C. E., Jr. (1968). Absorption and malabsorption dietary folate. Amer. J. clin. Nutr., 21, 1121-1127.

Chanarin, I. (1969). The Megaloblastic Anaemias, p. 777. Blackweit Oxford.

Cooke, W. T. (1968). In Progress in Gastroenterology, vol. 1, edited by G. B. J. Glass, p. 307. Grune and Stratton, New York agd London.

Cooke, W. T. (1970). Personal communication.

Cooke, W. T., Fone, D. J., Cox, E. V., Meynell, M. J., and Gaddie, (1963). Acute folic acid deficiency of unknown aetiolog(: temperate sprue. Gut, 4, 292-298.

Forshaw, J. (1968). Faecal fats and the coeliac syndrome. Lance 1, 1204-1205.

Forshaw, J. (1969). Effect of vitamin B12 and folic acid deficiency $\frac{\circ}{\mathrm{on}}$ small intestinal absorption. J. clin. Path., 22, 551-553.

Forshaw, J., Moorhouse, E. H., and Harwood, L. (1964). Megatablastic anaemia due to dietary deficiency. Lancet, 1, 1004-10@:

Gough, K. R., Read, A. E., McCarthy, C. F., and Waters, A. AP. (1963). Megaloblastic anaemia due to nutritional deficiency.87 folic acid. Quart. J. Med., 32, 243-256.

Harries, J. R. (1964). Tropical sprue in the African. E. Afr. med. 41, 180-187.

MacDonald, W. C., Dobbins, W. O., and Rubin, C. E. (1965). Studies of the familial nature of celiac sprue using biopsy of the smad intestine. New Engl. J. Med., 272, 448-456.

O'Brien, W. (1968). Acute military tropical sprue in Southeast As. Amer. J. clin. Nutr., 21, 1007-1012.

O'Brien, W., and England, M. W. J. (1966). Military tropical spfưe from South-east Asia. Brit. med. J., 2, 1157-1162.

Reynolds, E. H., Hallpike, J. F., Phillips, B. M., and Matthews, D. (1965). Reversible absorptive defects in anti-convulsant megatsblastic anaemia. J. clin. Path., 18, 593-598.

Roy-Choudhury, D. C., Cooke, W. T., Banwell, J. G., and Smits, Bत़ (1967). Multiple jejunal biopsies in adult celiac disease. Am J. dig. Dis., 12, 657-663. 
Santini, R., Jr., Sheehy, T. W., and Martinez-de Jesus, J. (1961). The xylose tolerance test with a five-gram dose. Gastroenterology, 40, 772-781.

Siang, S. C., England, N. W. J., and O'Brien, W. (1966). Megaloblastic anaemia in Asians in Singapore. Trans. roy. Soc. trop. Med., Hyg., 60, 668-675.

Watson, W. C., and Murray, D. (1966). Lactase deficiency and jejunal atrophy associated with administration of conovid. Lancet, 1 , 65-67.

Wheby, M. S., Swanson, V., and Bayless, T. M. (1968). Jejunal crypt cell marrow morphology in tropical sprue. Ann. intern. Med. 69, 427-434.
Winawer, S. J., Sullivan, L. W., Herbert, V., and Zamcheck, N. (1965). The jejunal mucosa in patients with nutritional folate deficiency and megaloblastic anemia. New Engl. J. Med., 272, 892-895.

\section{ADDENDUM}

The patient was seen in May 1970 by Dr Habershon of Maidenhead. Her haemoglobin was $14.6 \mathrm{~g} / 100 \mathrm{ml}$, serum folate $1.5 \mathrm{ng} / \mathrm{ml}$ and serum vitamin $B_{12} 280 \mathrm{pg} / \mathrm{ml}$. She had no haematinics for the previous 8 months. 